\title{
Empathy or Self-credibility? An Empirical Study of Intentions to Donate through Social Crowdfunding using the UTAUT Model
}

\author{
Nasrul Fahmi Zaki Fuadi ${ }^{1}$, Dessy Noor Farida ${ }^{2}$, Naili Saadah ${ }^{3}$ \\ zaki.fuadi@walisongo.ac.id¹,dessy_nf@walisongo.ac.id², naili_saadah@walisongo.ac.id ${ }^{3}$ \\ Universitas Islam Negeri Walisongo Semarang, Indonesia
}

\begin{abstract}
Millennial generation is the golden generation for all countries that own it. Because millennial generation is also referred to as a global generation in the world who wants ease of speed in all matters of life activities. As a global generation it is possible to interact with all the inhabitants of the world including in social matters. Social crowdfunding as a media that is the current trend seems to be a bridge for the wishes of the millennial generation to facilitate social interaction. By using UTAUT, this study investigates the acceptance of information and technology of social crowdfunding users in Java. Using online surveys and statistical tools, SPS collected 223 respondents. The results showed that performance expectancy (PE), effort expectancy (EE), social influence (SI), and facilitating conditions (FC) had a significant positive effect on behavioral intention of social crowdfunding users.
\end{abstract}

Keywords: UTAUT, Social Crowdfunding

\section{Pendahuluan}

Indonesia saat ini tengah mengalami fase baru dalam struktur demografi, sebuah fase yang lebih dikenal sebagai era bonus demografi. Bagi sebuah negara bonus demografi merupakan sebuah fenomena yang terjadi karena perubahan struktur penduduk yang disebabkan oleh rasio perbandingan antara jumlah penduduk nonproduktif lebih sedikit dibandingkan dengan usia produktif[1]. Pada fase inilah generasi milenial memiliki peran penting karena komposisi penduduk mayoritas berada pada rentang usia produktif. Mengutip pernyataan maria torocsik [2]dalam artikelnya menyebutkan bahwa generasi $\mathrm{Z}$ adalah generasi global pertama di dunia, oleh sebab itu generasi milenial yang mendominasi generasi $Z$ sangat responsif terhadap perkembangan teknologi. Sebagai salah satu negara berkembang yang memiliki jumlah populasi terbanyak didunia, globalisasi menjadi motor utama penggerak pertumbuhan ekonomi, sebagaimana yang diungkap[3] yang menyatakan bahwa globalisasi menjadi mesin penggerak utama yang mendongkrak pertumbuhan ekonomi sebuah negara berkembang. Demikian pula begitu dengan perkembangan teknologinya karena globalisasi dan teknologi merupakan dua hal yang harus disandingkan.

Globalisasi industri membebaskan sekat antarnegara dalam berinteraksi satu sama lain, begitupun dengan financial technology. Financial technologymenjadi bagian penting dalam era revolusi industri 4.0.Kemudahan dan keterjangkauan untuk mengakses segala sesuatu menjadi faktor kunci bagi semua sektor industri agar tetap bisa bertahan di era revolusi industri 4.0. Semua harus terkoneksi dengan internet, mungkin sudah menjadi hal wajib yang tidak bisa dihindari dalam era revolusi industri 4.0 ini. Menjadi benar apa yang dikatakan olehsetlur et al[4] bahwa inti revolusi industri keempat adalah interkoneksi antarberbagai hal atau yang lazim disebut internet of things. Hampir semua sektor industri berupaya untuk tetap bertahan di era revolusi industri 4.0 dengan berinovasi melalui produk-produk yang compatible untuk digunakan melalui platform tertentu. Salah satunya penghimpunan dana dari masyarakat melalui platform atau yang kita kenal dengan crowdfunding.

Crowdfunding merupakan terobosan baru dalam penggalangan dana, memungkinkan bagi crowdfunder untuk menghimpun dana dari masyarakat secara luas melalui platform tertentu baik yang bersifat profit ataupun nonprofit. Salah satu crowdfunding yang menjadi sorotan dalam penelitian ini adalah social crowdfunding. Social Crowdfunding sebagai fenomena baru dalam penggalangan dana berkembang cukup signifikan dari tahun 
ketahun, ditandai dengan mulai bermunculan platform crowdfunding antara lain Kitabisa.com, Wujudkan.com, patungan.com, Gandengtangan.com dll.

Berkembangnya platform berbasis social crowdfunding menjadi bukti nyata bahwa masyarakat indonesia menerima keberadaan platform berbasis crowdfunding sebagai bagian dari financial technology. Vankatesh et al[5] memperkenalkan sebuah model untuk mengukur penerimaan masyarakat dalam menggunakan sebuah teknologi. Unified theory of acceptance and use of technology (UTAUT) merupakan salah satu teori yang digaungkan oleh vankatesh et al. Rosnidah et al [6]dalam penelitianNya memberikan bukti bahwa semua variabel dalam teori UTAUT berpengaruh signifikan terhadap behavioral intentionuntuk menggunakan mobile payment di Indonesia. Dengan menggunakan teori yang sama [7]menyimpulkan hal yang sama dengan penelitian sebelumnya bahwa model UTAUT dan UTAUT2 berkontribusi terhadap behavioral intention untuk menerima dan menggunakan M commerce. Berlatar dari beberapa penelitian tersebut model UTAUT dipilih untuk menyoroti penggunaan platform crowfunding di Indonesia. Keberadaan crowdfunding sebagai bagian dari fintech menjadi daya tarik tersendiri bagi masyarakat indonesia, maraknya platform berbasis crowdfunding menjadi bukti bahwa antusiasiasme masyarakat indonesia cukup positif. Meskipun demikian penerimaan masyarakat akan platformcrowdfunding perlu ditinjau lebih dalam lagi. Akankah peningkatan penggunaan platformcrowdfundingmempengaruhi behavioral intention untuk menggunakan crowdfunding? Pertanyaan inilah yang mendasari perlunya penelitian lebih lanjut untuk mempelajari penerimaan pengguna crowdfunding di Indonesia.

\section{Pengembangan Teori}

\section{Crowdfunding}

Menurut Dibrova Crowdfunding adalah bentuk pembiayaan untuk perusahaan pertama kali lahir di Amerika Serikat dan telah berkembang secara internasional selama dua dekade terakhir[8]. Crowdfunding juga merupakan bentuk penggalangan dana online dari peserta yang kemudian didistribusikan dengan memberikan imbalan, sehingga crowdfunding telah menjadi sebuah alternative baru untuk penggalangan dana [9]. Literasi mengidentifikasi lima bentuk crowdfunding yang berbeda, yaitu berbasis donasi, berbasis imbalan, berbasis pinjaman, berbasis royalti, dan berbasis ekuitas[10]. Penggalangan dana melalui crowdfunding yang dikumpulkan dari publik melalui platform seperti jejaring sosial dapat digunakan untuk mendanai berbagai proyek, mulai dari produksi konten budaya atau artistik hingga pendirian startup [11].

Crowdfunding yang memadukan teknologi informasi (TI) dalampengumpulan sumbangan secara online[12], merupakan sebuah fenomena baru dan merupakan alat yangpopuler dimana menggabungkan teknologi informasi modern (Social Media) dengan penggalangan dana sosial[13]. Dalam model berbasis donasi, para donatur secara finansial mendukung kegiatan social crowdfunding tanpa janji menerima imbalan apa pun[14]. Sehingga kegiatan ini murni kepada kegiatan sosial kebajikan. Di Indonesia, platformcrowdfunding pertama yang muncul pada tahun 2012 adalahwujudkan.com. Setahun kemudian diikuti oleh platform crowdfunding berbasis donasi, seperti kitabisa.com dan patungan.net $[15,16]$.

\section{Unified Theory of Acceptance and Use of Technology (UTAUT)}

Dalam penelitian ini, peneliti menggunakan teori Unified Theory of Acceptance and Use of Technology (UTAUT) model untuk menganalisa faktor yang mempengarusi intensi publik dalam berdonasi di platform social crowdfunding. Model UTAUT berasal dari Theory of Reasoned Action (TRA) yang berdasarkan psikologi sosial [11]. Fishbein dan Ajzen [17] berpendapat dalam TRA bahwa sikap terhadap perilaku dan norma subyektif mempengaruhi niat perilaku dan sering kali dapat mengarah pada perilaku tertentu.Selain itu, Ajzen[18] menambahkan variabel "kontrol perilaku" dalam Theory of Planned Behavior (TPB), yang menyatakan bahwa "control perilaku" tidak hanya berpengaruh terhadap niat perilaku, tetapi juga memiliki pengaruh langsung pada perilaku individu.

UTAUTterbangun oleh empat penentu utama niat dan penggunaan, dan hingga empat moderator hubungan kunci[5]. Menurut model UTAUT, niat perilaku individu dipengaruhi oleh empat faktor inti, yaitu, 
performance expectancy (PE), effort expectancy (EE), social influence (SI), and facilitating conditions (FC). Model UTAUT telah banyak digunakan dalam penelitian tentang penerimaan pengguna terhadap teknologi informasi baru dan media baru[11]. Dalam studi ini, peneliti menganalisis faktor-faktor yang mempengaruhi niat publik untuk berdonasi pada kegiatan social crowdfundingyang berbasis platform yang tepat berdasarkan model UTAUT.

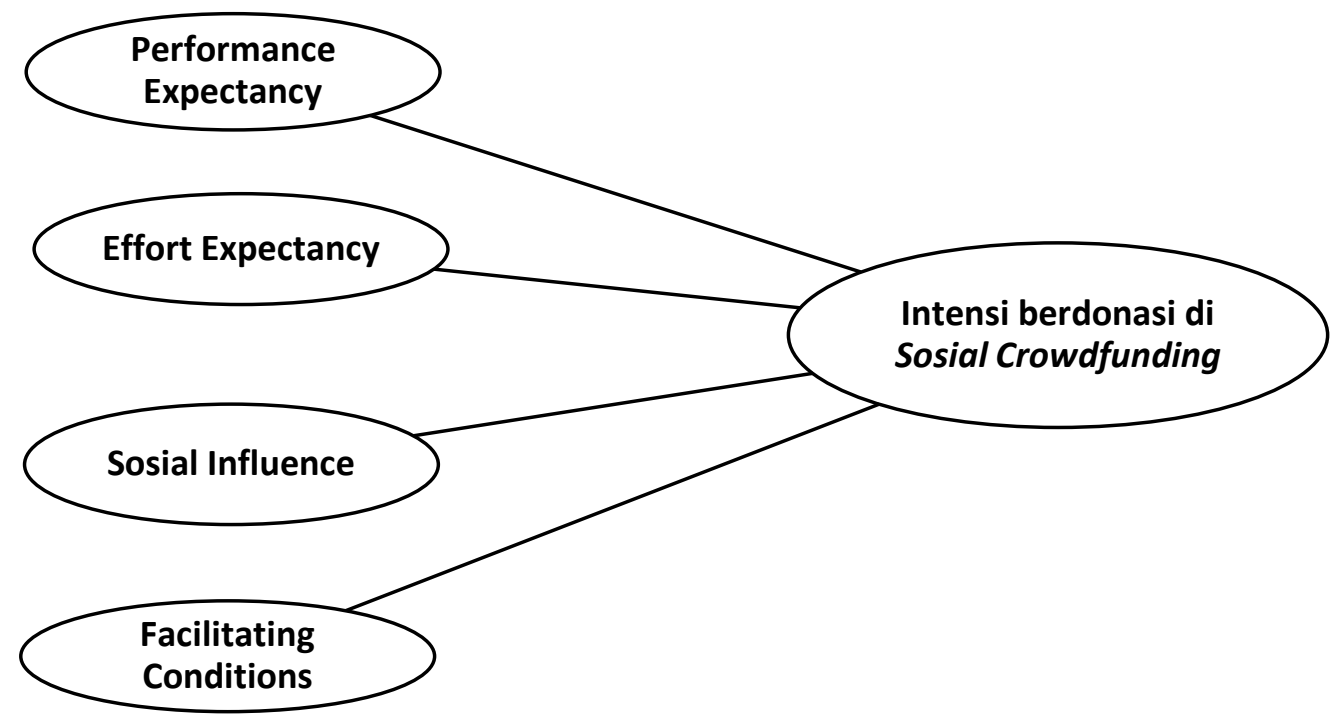

Gambar 1. Faktor intensi berdonasi di Social Crowdfunding (UTAUT)

\section{Performance expectancy (PE)}

Performance expectancyadalahkondisi seseorang percaya bahwa menggunakan suatu sistem akan membantunya untuk mendapatkan manfaat dalam kinerja pekerjaan [5].Dalam konteks social crowdfunding, perilaku sumbangan dana dapat dipengaruhi oleh keinginan untuk terhindar darihinaan/celaan orang lain atau untuk mendapatkan pujian sosial dan pengakuan sosial, untuk merangsang interaksi sosial[13]. Ketika seseorang melakukan donasi pada social crowdfunding maka akan merasakan kepuasan dalam diri sehingga mampu meningkatkan harga diri di lingkungannya. Dan kepuasan diri tersebut memiliki dampak positif pada kesediaan mereka untuk berpartisipasi. Sehinggapeneliti mendefinisikan PE sebagai sejauh mana donatursocial crowdfunding percaya bahwa dengan menggunakan platformcrowdfunding untuk menyumbangkan uang akan membantunya mendapatkan kepuasan pribadi, interaksi sosial, pengakuan sosial, dan pencapaian pribadi [19]. Berlatar uraian tersebut maka hipotesis yang peneliti rumuskan:

H1: Performance Expectancy berpengaruh positif signifikan terhadap intensi berdonasi

\section{Effort expectancy (EE)}

Effort expectancyadalah tingkat kemudahan yang dirasakan seseorang dalam penggunaan suatu sistem [5]. Tiga konstruksi dari model yang ada dariEE, yaitu persepsi kemudahan penggunaan (TAM / TAM2), kompleksitas (MPCU), dan kemudahan penggunaan (IDT).Hasil penelitian menunjukkan bahwa kemudahan dalam menggunakan teknologi dapat berpengaruh signifikan terhadap niat untuk berperilaku [20]. Sehingga penelitimengasumsikan bahwa kemudahan penggunaanplatformcrowdfunding dan kenyamanan proses donasi berpengaruh positif signifikan terhadapintensi pengguna untuk menyumbang. Berdasarkan uraian tersebut maka peneliti merumuskan hipotesis sebagai berikut:

H2:Effort expectancy berpengaruh positif signifikan terhadap intensi berdonasi 


\section{Social influence (SI)}

Social influenceadalah sejauh mana seseorang memandang bahwa orang-orang yang dianggap penting percaya bahwa ia harus menggunakan sistem baru[5]. SI sebagai penentu langsung niat perilaku direpresentasikan sebagai norma subyektif dalam TRA, TAM2, TPB / DTPB dan C-TAM-TPB, faktor sosial di MPCU, dan gambar di IDT. Dalam konteks social crowdfunding, tanggung jawab sosial seseorang, intensi untukberdonasi dapat dipengaruhi oleh tekanan dari teman sebaya[13].Oleh karena itu, rasa tanggung jawab sosial dan pengaruh orang lain diambil sebagai dua dimensi utama dari faktor Social Influence. Tindakan amal individu juga tergantung pada jumlah total sumbangan orang lain[19]. Berdasarkan uraian tersebut maka hipotesis yang kita rumuskan adalah:

H3: Social influence berpengaruh positif signifikan terhadap intensi berdonasi

\section{Facilitating conditions (FC)}

Facilitating conditionsadalah sejauh mana seseorang percaya bahwa infrastruktur organisasi dan teknis ada untuk mendukung penggunaan sistem [5].Definisi ini menggambarkan bahwa konsep ini diwujudkan oleh tiga konstruk yang berbeda: kontrol perilaku yang dirasakan (TPBI DTPB, C-TAM-TPB), kondisi fasilitasi (MPCU), dan kompatibilitas (IDT). Masing-masing variabeltersebut dioperasionalkan untuk mencakup aspek lingkungan teknologi dan / atau organisasi yang dimaksudkan untuk menghilangkan kesulitandalam penggunaan. Menurut model UTAUT, kontrol perilaku yang dirasakan dan faktor objektif ekstrinsik dapat berdampak langsung pada penggunaan sistem informasi Internet[5]. Dalam konteks social crowdfunding, keragaman sumber informasi dan representasi media yang berbeda dari kegiatan social crowdfunding, termasuk media sosial, sering mengakibatkan peningkatan kesadaran dan niat untuk berdonasi di social crowdfunding[9]. Berdasarkan uraian tersebut maka hipotesis yang peneliti rumuskan adalah:

H4: Fasicilitating conditions berpengaruh positif signifikan terhadap intensi berdonasi

\section{Metodologi Penelitian}

Metode pengumpulan data yang digunakan dalam penelitian ini adalah online survey dengan menggunakan googleform sebagai media. Sedangkan untuk pengumpulan sampel dalam penelitian ini menggunakan metode random sampling di Pulau Jawa dengan responden masyarakat yang telah mengenal social crowdfunding seperti (patungan.com, kitabisa.com, wujudkan.com, gandengtangan.com, ayopeduli.com). pengujian hipotesis dalam penelitian ini menggunakan metode regresi linear berganda dengan alat statistik SPSS untuk menguji empat hipotesis yang diajukan dalam penelitian ini.

\section{Hasil dan Pembahasan}

\section{Hasil Statistik Deskriptif}

Berdasarkan data obeservasi sebanyak 223 respondendengan jenis kelamin perempuan lebih banyak di bandingkan dengan responden laki-laki sebesar 56,1\%. Mayoritas responden berusia 25-55 tahun yang berada di usia produkif dan merupakan pekerja. Hampir 55,4\% responden berpendidikan S-2 dan hanya $10 \%$ yang berpendidikan S-3.Untuk jenis pekerjaan, profesi PNS/BUMN berada di kisaran 36,2\% dan diikuti dengan swasta yang ada di kisaran 32,1\% dengan penghasilan berkisar 2-5 juta sebanyak 48\%.

\section{Uji Validitas dan Uji Reliabilitas}

Keabsahan dan kevalidan indikator pertanyaan kuesioner diukur dengan menggunakan uji validitas dan uji reliabilitas. Hasil dari uji validitas dan reliabilitas adalah sebagai berikut: 
Tabel 1. Hasil uji Validitas dan Reliabilitas

\begin{tabular}{|c|c|c|c|c|c|c|}
\hline & Item & $\begin{array}{l}\text { Performance } \\
\text { Expectancy }\end{array}$ & $\begin{array}{l}\text { Effort } \\
\text { Expectancy }\end{array}$ & $\begin{array}{l}\text { Social } \\
\text { Influence }\end{array}$ & $\begin{array}{l}\text { Facilitating } \\
\text { Condition }\end{array}$ & $\begin{array}{l}\text { Intention } \\
\text { to Donate }\end{array}$ \\
\hline \multirow{4}{*}{$\begin{array}{c}\text { Performance } \\
\text { expectancy }\end{array}$} & PE1 & 0,407 & & & & \\
\hline & PE2 & 0,494 & & & & \\
\hline & PE3 & 0,548 & & & & \\
\hline & PE4 & 0,517 & & & & \\
\hline \multirow{4}{*}{$\begin{array}{l}\text { Effort } \\
\text { Expectancy }\end{array}$} & PEU1 & & 0,523 & & & \\
\hline & PEU2 & & 0,688 & & & \\
\hline & PEU3 & & 0,723 & & & \\
\hline & PEU4 & & 0,636 & & & \\
\hline \multirow{4}{*}{$\begin{array}{l}\text { Social } \\
\text { Influence }\end{array}$} & SI1 & & & 0,425 & & \\
\hline & $\mathrm{SI} 2$ & & & 0,561 & & \\
\hline & $\mathrm{SI} 3$ & & & 0,507 & & \\
\hline & SI4 & & & 0,289 & & \\
\hline \multirow{3}{*}{$\begin{array}{l}\text { Facilitating } \\
\text { condition }\end{array}$} & FC1 & & & & 0,546 & \\
\hline & $\mathrm{FC} 2$ & & & & 0,630 & \\
\hline & FC3 & & & & 0,517 & \\
\hline \multirow{5}{*}{$\begin{array}{l}\text { Intention to } \\
\text { donate }\end{array}$} & In 1 & & & & & 0,891 \\
\hline & In 2 & & & & & 0,941 \\
\hline & In3 & & & & & 0,936 \\
\hline & $\begin{array}{l}\text { Cronbach's } \\
\text { alpha }\end{array}$ & 0,711 & 0,817 & 0,700 & 0,737 & 0,964 \\
\hline & r-Table & 0,1104 & 0,1104 & 0,1104 & 0,1104 & 0,1104 \\
\hline
\end{tabular}

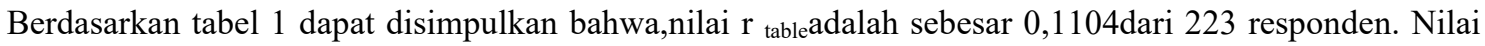

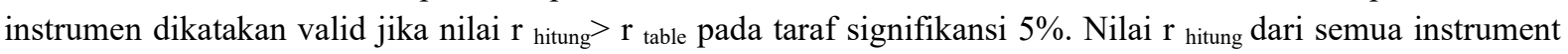
pada Table 1 menunjukkan bahwa lebih besar dari 0,1104, sehingga dapat dikatakan semua instrumen dinyatakan memenuhi uji validitas. Uji Reliabilitas diukur dengan menggunakan Teknik Alpha Cronbach. Jika nilai Cronbach's Alpha lebih besar sama dengan 0,7 maka jawaban dari para responden pada kuesioner sebagai alat pengukur dinilai reliabel. Dari tabell dapat dilihat bahwa semua instrumen penelitian, nilai cronbach's alpha-nya lebih besar sama dengan 0,7, sehingga dapat disimpulkan semua instrumen dinyatakan memenuhi uji reliabilitas.

\section{Analisis Regresi}

Tabel 2.Uji Asumsi Klasik

\begin{tabular}{llcc}
\hline Uji Multikolonieritas & Tolerance & VIF \\
\hline - & Performance Expectancy & 0.700 & 1.428 \\
- & Social Influence & 0.793 & 1.260 \\
- Facilitating Condition & 0.602 & 1.662 \\
\end{tabular}

Uji Heteroskedastisitas (Glejser test)

- Performance Expectancy

- Effort Expectancy

- Social Influence

- Facilitating Condition

Durbin-Watson test

\section{Normality Test}

\begin{tabular}{llc} 
- & kolmogorov- Smirnov test & 0,190 \\
\hline & Adj R Square & 0.449
\end{tabular}

Sig. t-test

$$
\begin{aligned}
& 0.700 \\
& 0.793 \\
& 0.602 \\
& 0.689 \\
& 1.972
\end{aligned}
$$


Berdasarkan tabel 2 dapat disimpulkan bahwa data penelitian memenuhi semua syarat uji asumsi klasik yang meliputi uji multikolonieritas, uji heteroskedastisitas, uji autoorelasi dan uji normalitas. Adjusted $\mathrm{R}^{2}$ dari penelitian ini adalah 0,449 yang artinya adalah variable performance expectancy, effort expectancy, social influence dan facilitating condition bisa menjelaskan variable intention to donate sebesar 44,9\%, selebihnya sebesar 55,1\% dijelaskan karena faktor lain.

\section{Uji Hipotesis}

Tabel 3.Pengujian Hipotesis

\begin{tabular}{lccc}
\hline Variabel bebas & & & \\
\hline Pengujian hipotesis & Coefficient & t value & Sign \\
\hline - Performance Expectancy & 0.137 & 2.839 & 0.005 \\
- $\quad$ Socfort Expectancy & 0.219 & 5.292 & 0.000 \\
- $\quad$ Facilitating Condition & 0.273 & 4.420 & 0.000 \\
\hline
\end{tabular}

Sumber: Data sekunder yang diolah (2019)

Berdasarkan hasil pengujian hipotesis yang dilakukan dengan menggunakan uji $\mathrm{t}$ pada tabel 3 menunjukkan keempat hipotesis yang diajukan dalam penelitian ini berada di bawah 0,05 yang berarti semua hipotesis yang diajukan dalam penelitian ini diterima.

Performance expectancy dapat diartikan sejauh mana seseorang percaya bahwa dengan menggunakan suatu sistem akan dapat membantu untuk mendapatkan keuntungan dalam kinerjanya [21]. Menurut Hui,J.S., et al, (2012)Social Crowdfunding (penggalangan dana dari sejumlah besar orang untuk mendanai suatu proyek/amal yang umumnya dilakukan melalui internet) dapat dimotivasi karena adanya keinginan untuk adanya pengakuan sosial sehingga dapat memotivasi interaksi sosial. Ketika sesorang mengambil bagian dalam social crowdfunding, kepuasan diri mereka akan meningkat sehingga akan berdampak positif terhadap keinginan atau kesediaan mereka untuk berpartisipasi. Larralde (2010) dalam (Li, et al, 2017) mengungkapkan bahwa kepuasan diri sebagai faktor pendorong utama seseorang untuk ikut berpatisipasi dalam kegiatan social crowdfunding. Seseorang yang berhasil menyukseskan suatu proyek amal akan memberikan rasa kepuasan tersendiri bagi pendonor sebagai wujud dari prestasi mereka.

Effort Expectancy merupakan tingkat kemudahan yang terkait dengan penggunaan suatu system. Jika system dalam penggalangan dana amal mudah di operasionalkan atau dioperasikan maka seseorang akan merasa mudah untuk bergabung dan beramal di sistem tersebut. Sehingga hal ini akan memudahkan niat donatur untuk menyumbangkan atau mendonasikan uang mereka ke proyek tersebut.

Social influence merupakan persepsi individu tentang pentingnya sesuatu hal bagi orang lain ketika individu tersebut menggunakan suatu sistem baru. Menurut penelitian yang dilakukan Boris (1987) dalam [13] motivasi individu untuk beramal adalah berhubungan dengaan tanggungjawab sosial, agama dan filosofi pribadi. Individu yang memiliki rasa tanggungjawab sosial yang kuat kemungkinan besar untuk turut berpartisipasi untuk beramal melalui social crowdfunding. Selain itu tindakan amal individu juga bergantung pada jumlah total sumbangan orang lain ([13]. Jadi besarnya sumbangan individu akan memengaruhi besarnya sumbangan yang kita berikan. Jadi rasa tanggungjawab sosial dan pengaruh orang lain dianggap sebagai dua dimensi utama dalam faktor Social Influence.

Facilitating condition merupakan sejauh mana seseorang percaya bahwa keberadaan organisasi dan infrastruktur teknis mendukung penggunaan sistem. Menurut model UTAUT, penerimaan pengendalian perilaku dan factor tujuan ekstrinsik dapat berdampak langsung pada penggunaan sistem informasi internet [21]. Penelitian sebelumnya menunjukkan bahwa keberagamana sumber informasi dan pemakaian media yang berbeda dalam mempromosikan suatu proyek amal, termasuk media sosial, akan meningkatkan kesadaran dalam melakukan sosial crowdfunding[23]. Sehingga ketika ada suatu proyek amal, donatur akan melihat publikasi proyek amal tersebut di media sosial, keragaman informasi proyek dalam situs penyelenggara dan akan melihat 
siapa pihak penyelenggaranya untuk memastikan bahwa uangnya akan aman dalam proyek tersebut. Dan dengan begitu maka akan semakin menguatkan motivasi pendonor untuk beramal melalui proyek tersebut.

\section{Kesimpulan}

Sosial crowdfunding merupakan kegiatan pengumpulan dana amal dari banyak orang melalui internet. Dengan menggunakan internet, cakupan pendonor akan lebih luas sehingga tujuan dari sosial crowdfunding akan mudah terlaksana. Sosial crowdfunding telah mengubah cara orang untuk mengumpulkan dana dari para pendonor untuk mewujudkan ide-ide baru. Dari hasil penelitian ini terbukti bahwa semua variabelmemiliki dampak positif terkait dengan intensi seseorang untuk berdonasi.Variabelperformance expectanc, Effort Expectancy, Social influencedan Facilitating condition ternyata mampu untuk memberikan motivasi seseorang untuk melakukan donasi pada suatu proyek amal melalui internet (social crowdfunding).Keterbatasan dari penelitian ini adalah masih adanya faktor lain yang memengaruhi intensi seseorang untuk berdonasi yang belum di masukkan dalam penelitian ini. Saran untuk peneliti selanjutnya adalah memasukkan variabel lain yang memungkinkan dapat memengaruhi intensi untuk berdonasi misalkan variabel religiusitas, kepercayaan dan faktor-faktor lainnya.

\section{References}

[1] Budiati I, Susianto Y, Adi WP, Ayuni S, Reagan HA, Larasaty P, et al.: Profil Generasi Milenial Indonesia. Jakarta: Kementerian Pemberdayaan Perempuan dan Perlindungan Anak (2018)

[2] Töröcsik M, Szücs K, Kehl D. How Generations Think: Research on Generation Z. Communicatio 2014;1:23-45.

[3] Personal M, Archive R, Henk LM, Kyvik H, Analysis EP. [WIP] Mp r a. Econ Policy 2007:0-33. doi:10.1227/01.NEU.0000349921.14519.2A.

[4] Setlur B, Iyer G, Varadan S.: Informed Manufacturing: The Next Industrial Revolution COGNIZANT. Chennai, India (2014)

[5] Venkatesh, Morris, Davis, Davis. User Acceptance of Information Technology: Toward a Unified View. MIS Q 2003;27:425-78. doi:10.2307/30036540.

[6] Rosnidah I, Muna A, Musyaffi AM, Siregar NF. Critical Factor of Mobile Payment Acceptance in Millenial Generation: Study on the UTAUT model 2019;306:123-7. doi:10.2991/isseh-18.2019.30.

[7] Imtiaz S. The Studies of Unified Theory of Acceptance and Use of Technology ( UTAUT ) in MCommerce Context 2018:42-56.

[8] Paoloni P, Paoloni N, Modaffari G. Crowdfunding as a new collaborative process in the knowledge economy. VINE J Inf Knowl Manag Syst 2019;49:241-55. doi:10.1108/VJIKMS-12-2018-0118.

[9] Gerber EM, Hui J. Crowdfunding: Motivations and deterrents for participation. ACM Trans Comput Interact 2013;20. doi:10.1145/2530540.

[10] Belleflamme P, Lambert T. An Industrial Organization Framework to Understand the Strategies of Crowdfunding Platforms. Int. Perspect. Crowdfunding, Emerald Group Publishing Limited; 2016, p. 119. doi:10.1108/978-1-78560-315-020151001.

[11] Moon Y, Hwang J. Crowdfunding as an alternative means for funding sustainable appropriate technology: Acceptance determinants of backers. Sustain 2018;10:1-18. doi:10.3390/su10051456.

[12] Bradford CS.: Crowdfunding and the Federal Securities Laws (2012)

[13] Li Y-Z, He T-L, Song Y-R, Yang Z, Zhou R-T. Factors impacting donors' intention to donate to 
charitable crowd-funding projects in China: a UTAUT-based model. Information, Commun Soc 2017;21:404-15. doi:10.1080/1369118X.2017.1282530.

[14] Messeni Petruzzelli A, Natalicchio A, Panniello U, Roma P. Understanding the crowdfunding phenomenon and its implications for sustainability. Technol Forecast Soc Change 2019. doi:10.1016/j.techfore.2018.10.002.

[15] Piliyanti I. Fintech Achieving Sustainable Development: The Side Perspective of Crowdfunding Platform. Shirkah J Econ Bus 2019. doi:10.22515/shirkah.v3i2.207.

[16] Achsien IH, Purnamasari DL. Islamic Crowd-funding as The Next Financial Innovation in Islamic Finance: Potential and Anticipated Regulation in Indonesia. Eur J Islam Financ 2016. doi:10.13135/2421-2172/1771.

[17] Fishbein M, Ajzen I.: Belief, Attitude, Intention, and Behavior: An Introduction to Theory and Research. Reading, MA, USA: Addison-Wesley (1977)

[18] Ajzen I. The theory of planned behavior. Organ Behav Hum Decis Process 1991;50:179-211. doi:10.1016/0749-5978(91)90020-T.

[19] Li Y, He T, Song Y, Yang Z, Zhou R. Factors impacting donors' intention to donate to charitable crowd-funding projects in China: a UTAUT-based model 2017;4462:1-12. doi:10.1080/1369118X.2017.1282530.

[20] Wang N, Shen X, Sun Y. Transition of electronic word-of-mouth services from web to mobile context : A trust transfer perspective. Decis Support Syst 2013;54:1394-403. doi:10.1016/j.dss.2012.12.015.

[21] Venkatesh V, Davis, F D. User Acceptance of Information Technology : Toward a Unified View. MIS Q 2003;8:425-78.

[22] Hui J, Gerber E, Greenberg M.; Easy Money? The Demands of Crowdfunding Work. Proc. Segal Tech. Rep (2012)

[23] Gerber EM, Hui J.: Crowdfunding : Motivations and Deterrents for Participation. ACM Trans Comput Hum Interact 2015;20:1-32. 